DOI: $10.14451 / 2.138 .7$

\title{
ОБЩЕПРОЦЕССУАЛЬНОЕ ПРАВОПРЕЕМСТВО: КОНЦЕПТУАЛЬНЫЕ ОСНОВЫ
}

\author{
(c) 2019 Агеева Галина Евгеньевна \\ кандидат юридических наук, доцент, \\ доцент кафедры гражданского и арбитражного процесса \\ Самарский государственный экономический университет, Россия, Самара \\ E-mail: galinaageevva@mail.ru \\ (c) 2019 Губайдуллина Э.X. \\ кандидат юридических наук, \\ доцент кафедры гражданского и арбитражного процесса \\ Самарский государственный экономический университет, Россия, Самара \\ E-mail: elmira_zaripova@mail.ru \\ (c) 2019 Рябова Инна Сергеевна \\ студент-магистрант юридического факультета \\ Самарский государственный экономический университет, Россия, Самара \\ E-mail: innochka-ryabova@list.ru
}

Настоящее исследование посвящено юридическому институту правопреемства. Авторы уделяют внимание обозначению концептуальных основ процессуальной сущности правопреемства, выделению его основных характеристик. Правопреемство в самом общем виде представляет собой замену одного субъекта в правоотношениях другим. Подобная рокировка может быть осуществлена не только в порядке отправления правосудия, однако традиционно институт правопреемства изучается либо с позиции гражданского права в рамках раздела об исполнении обязательств, либо с позиции гражданского процесса. В связи с чем важно упомянуть также отсутствие в современной юридической науке каких-либо комплексных исследований процессуального порядка реализации института правопреемства не только с позиции судебного правоприменения, что также свидетельствует об актуальности данной работы. Цель настоящего исследования заключается в комплексном изучении правопреемства с позиции его общепроцессуального значения, обозначении концептуальных основ подобного подхода и необходимости восполнения пробела общетеоретического изучения данной темы. Объектом данной работы выступают общественные отношения, протекающие в порядке замены одного субъекта другим в силу объективных или субъективных причин в различных видах процессуальной деятельности. Понимание процессуальной деятельности в данном контексте не связывается с конкретным видом судопроизводства или обязательственных отношений. Предмет настоящего исследования представлен авторским подходом к пониманию юридического процесса и процессуальной деятельности и состоит из теорий, концепций, нормативных и правоприменительных материалов, затрагивающих правопреемство. Теоретико-методологическое значение выделения концептуальных основ общепроцессуального понимания института правопреемства состоит в обогащении правовой науки новым подходом, знаниями, связанными с комплексным пониманием сущности и особенностей замены одного субъекта другим в различных видах отношений. Практическое значение данной темы состоит в том, что апробация выработанных теоретико-методологических подходов на практике способна повысить эффективность функционирования правопреемства и снизить ряд негативных явлений.

Ключевые слова: правопреемство; юридический процесс; судебное право; субъекты юридического процесса; замена лиц.

Безусловно, современная юридическая наука меняет свой концептуальный облик. Современный этап развития правового знания характеризуется возникновением новых теорий, концепций, построение и функционирование которых нуждается в философском, правовом осмыслении, а затем уже и в апробации на практике, поскольку именно практика выступает 
своего рода мерилом верности правовых знаний и, следовательно, эффективности разработанных теоретических концепций.

На современном этапе развития и функционирования правовой системы продолжает расширяться и набирает обороты теория, так называемого широкого юридического процесса. Современные правоведы, высказывающиеся о необходимости формирования и самостоятельного выделения в теории государства и права процессуальной теории, по-прежнему, субъективно подходят к пониманию структуры процессуальной деятельности и, соответственно, процессуального права, как системы норм, посвященной ее правовой регламентации [1].

Полагаем, что институт правопреемства, активно функционирующий в различных отраслях российского права, необходимо анализировать, прежде всего, как общепроцессуальный, ввиду того, что его особенности осуществления всегда связаны с деятельными аспектами и практическими нюансами. Ввиду чего, исследование института правопреемства в качестве общепроцессуального способно существенным образом обогатить правовую науку и в случае апробация выработанных теоретико-методологических подходов на практике повысить эффективность его функционирования и снизить ряд негативных явлений.

Повышение интенсивности гражданского оборота неизбежно влечет за собой увеличение уровня мобильности не только объектов гражданских прав, но и самих субъектов гражданских правоотношений. Смена организационно-правовых форм организаций, сделки, направленные на перемену лиц в обязательствах, изменение правового статуса субъектов влекут за собой проявление повышенного внимания к институтам правопреемства во всех материальных отраслях права. Особенно характерен исследуемый институт для «традиционно» процессуальных отраслей права [2].

Процессуальное право в любой своей отрасли (а тем более в области гражданских отношений) настолько тесно связано с личностью гражданина, что осуществление смены лиц в ходе процесса может существенно повлиять на окончание процессуальных отношений (например, на вынесенное итоговое решение по делу в судебном праве).

Нормами гражданского законодательства, определено, что участниками гражданских пра- воотношений выступают физические и юридические лица. Но каждый из этих субъектов ограничен временными рамками своего существования и в большинстве случаев, в зависимость от этого ставится и существование самих гражданских правоотношений. В любой отрасли права закреплен перечень тех юридических фактов, с наступлением которых связывают изменение или прекращение отношений между сторонами. К ним относится, например, смерть физического лица, признание его недееспособными или же ограниченно дееспособным, объявление гражданина безвестно отсутствующим или умершим, ликвидация юридического лица, выход из состава организации [3]. В то же время на практике возникают случаи, когда даже, несмотря на отсутствие носителя конкретных субъективных прав и обязанностей, возникших в процессе правоотношения, прекращение их считается нецелесообразным, в силу возможного нарушения прав и интересов других участников этих отношений. Для обеспечения защиты прав и иных охраняемых законом интересов лиц, была разработана правовая конструкция универсального правопреемства. В ходе ее реализации все права и обязанности, ранее принадлежавшие одному лицу, переходят к его, так называемому правопреемнику для защиты прав собственников при определении судьбы принадлежащего им имущества, на случай наступления непредвиденных обстоятельств.

Традиционно научно-исследовательский интерес правопреемство привлекало в сфере проявления в материальном праве. Постепенно институт правопреемства транспонировался и в нормы различных отраслей процессуального права, тем более в процессе формирования широкого понимания процессуального права. Особенно это значимо для судебного права - ведь при осуществлении производства по гражданскому или административному делам, безусловно, важно учитывать интересы лиц, выступающих носителями конкретных прав и обязанностей спорного правоотношения, и, в случае выбытия одного из них в силу непредвиденных жизненных обстоятельств, не должно мешать должному осуществлению защиты прав и интересов остальных участников процесса.

Как отмечает В.Д.Носов, начало изучения феномена правопреемства восходит к римскому частному праву, в котором осуществление преемства в правах и обязанностях не допускалось 
в силу, того, что они представлялись принадлежащими только гражданину (т.е. личными), не подлежащими переходу от одного лица к другому [4]. Но постепенно в процессе развития гражданских правоотношений возникла необходимость в перераспределении благ, возможности обеспечения их постоянного действия вне зависимости от каких либо жизненных обстоятельств, включая субъектов.

Согласно положениям римского права в порядке правопреемства могли переходить только имущественные права и обязанности, а также те обязательства, которые влекли за собой определенные имущественные последствия для участвующей стороны [5]. И собственники именно для защиты своих прав на имущество разработали конструкцию универсального правопреемства - когда правопреемник приобретал все права и обязанности собственника в отношении конкретной вещи. Возможность же сингулярного (частичного) правопреемства появилась намного позднее, с развитием отношения торговли и денежного оборота, что способствовало осуществлению этих операций со значительной экономией во времени.

Исходя из сущности правопреемства, в нем можно выделить следующие основные признаки: замена участников правоотношения и осуществление перехода прав и обязанностей от одного лица к другому, осуществляется на основании одного и того же юридического факта; существующее правоотношение сохраняется в неизменном виде, меняется только его субъектный состав.

В российской юридической науке сложилось общее мнение о том, что правопреемство представляет собой межотраслевой правовой институт, позволяющий осуществлять замену лиц в правоотношениях [6]. Полагаем, что правопреемство - не только межотраслевой институт, но и общепроцессуальный институт ввиду его существенных характеристик, напрямую связанных с юридической деятельностью.

Авторы настоящего исследования подходят расширительно к пониманию процессуального права[7, 8]. Уже около ста лет [9] в российской юридической науке пытаются расширить понимание процессуального права: сначала за счет теоретического объединения различных видов судопроизводства, в том числе не оформленных отдельным законодательным актом (речь идет об административном судопроизводстве). Впо- следствии исследователи начали отмечать, что любая деятельность с участием государственновластных субъектов, затрагивающая разрешение конфликтов или устранение противоречий между субъектами (не только в судах, но и в иных административных органах) по своей сущности и процедурным особенностям схожа. Ввиду чего к процессуальному праву было предложено относить нормы, регулирующие юрисдикционный правоприменительный процесс. Позже учеными было обращено внимание на то, что любая позитивная правоприменительная деятельность (например, регистрация или выдача лицензий), а впоследствии и правореализационная (заключение договоров, к примеру) также может считаться юридическим процессом.

Если исходить из подобных методологических подходов, то к процессуальному праву можно отнести любые правовые нормы, регулирующие различные виды юридической деятельности [10]. В числе особенностей процессуальной деятельности можно выделить:

1. динамичный характер, присутствие стадийности;

2. регулирование нормами права;

3. совокупность осуществляемых действий направлена на достижение заранее известного юридически-значимого результата;

4. итог процессуальной деятельности всегда имеет определенные правовые последствия, ради достижения которых субъекты права изначально и реализовывали свои права.

Исходя из вышеизложенных методологических подходов к пониманию процессуального права, хочется подчеркнуть, что правопреемство в самом общем виде - это замена одного лица другим, следовательно, это всегда активная, деятельная операция, имеющая определенную правозначимую цель. Ввиду чего, правопреемство, вне зависимости от реализации в традиционно материальных или процессуальных отраслях права, представляет собой общепроцессуальный институт, имеющей схожие особенности осуществления.

Рассуждая о значимости понимания и исследования института правопреемства с общепроцессуальной позиции, хочется выделить основные концептуальные особенности, нуждающиеся в дальнейшей общетеоретической разработке:

1. Институт правопреемства в настоящее время представляет собой институт замены лиц 
в обязательстве, который имеет ярко-выраженный отраслевой аспект. Исследование института правопреемства с общепроцессуальной позиции до настоящего момента не производилось.

2. В процессуальном понимании, правопреемство - это замена лица, выступающего стороной в процессе (истцом или ответчиком в судебном праве или другим участником любого иного вида юридического процесса) другим лицом в течение процесса, после чего его предшественник полностью и без каких-либо последствий выбывает из процессуальных правоотношений и заменяется вступившим в него лицом, который обладает одинаковым набором процессуальных прав и обязанностей, передаваемых ему выбывшим

участником. Процесс в таких случаях продолжает оставаться единым, поскольку в нем продолжает или рассматриваться одно и то же исковое требование (судебное право), или реализоваться тот же объем правомочий (лицензионный или договорный процессы, например).

3. В теории процессуального права наукой к настоящему моменту выработано три видовых модели правопреемства: 1) обязательное (в данном случае важен сам факт - лицо покинуло процесс и для данных отношений замена - обязательна); 2) волевое (само по себе правопреемство не наступает, но если два субъекта имеют желание «поменяться», то могут реализовать предоставленное право); 3) смешанное (присут- ствуют черты первых двух видов). По нашему мнению, для повышения эффективности правоприменительной правореализационной практик на современном этапе в процессуальном праве требуется не только расширение моделей правопреемства и его оснований на законодательном уровне, но и распространение единых унифицированных правил порядка замены одного субъекта другим на все виды процессуальной деятельности.

4. Также хотелось бы отметить, что, несмотря на то, что положения о процессуальном правопреемстве достаточно проработаны, проблемы в правоприменительной практике все же возникают. Связаны они в большинстве своем с правопреемством в результате реорганизации организации. Немало спорных вопросов возникает с правопреемством на стадии исполнения судебного решения, а также в отдельном виде производства по делу - в приказном производстве. Все это обуславливает необходимость, во-первых, унификации правовых предписаний отраслевого законодательства, которое содержит положения о правопреемстве, а во-вторых, в обобщении материалов судебной практики по вопросам правопреемства и закрепление их с пояснениями. Данные меры позволят улучшить качество производства по делам и обеспечить надлежащую реализацию прав граждан на судебную защиту.

\section{Библиографический список}

1. Ageeva G.E. Digitalization of the Openness Principle of Civil Proceedings: Enunciation Issues // Current Achievements, Challenges and Digital Chances of Knowledge Based Economy: Part of the Lecture Notes in Networks and Systems book series (LNNS, volume 133). P. 707-712. URL: https://link.springer.com/book/10.1007\%2F9783-030-47458-4?page $=1$ \#toc.

2. Макарьян Д. Стороны в гражданском процессе// Юридическая наука. 2015. № 1 .

3. Гражданский кодекс Российской Федерации (часть первая) от 30.11.1994 N 51-Ф3 (ред. от 03.08.2018) // СПС КонсультантПлюс

4. Носов Д.В. Феномен правопреемства в российской правовой системе// Журнал российского права. 2011. № 2. C.74.

5. Гражданское право: Учебник. В 2 т. Под ред. Гонгало Б. М. Т.1. 2-е изд., переработ. и доп. М.: Юрайт, 2017. С. 105.

6. Васильев Г. С. Преемство в праве собственности как разновидность сингулярного правопреемства// Правоведение. 2011. № 6. С.48.

7. Губайдуллина Э. Х. Спор в праве: теоретико-правовой аспект: дис. ... канд. юрид. наук. Самара, 2017.

8. Агеева Г.Е. Оценочные понятия в процессуальном праве: дис. .... канд. юрид. наук. Самара, 2014.

9. Рязановский В.А. Единство процесса. М., 1996. С. 18 (напечатано по изданию: Рязановский В.А.Единство процесса // Труды профессоров Иркутского университета. Вып. 1. Иркутск, 1920).

10. Павлушина А. А. Теория юридического процесса: итоги, проблемы, перспективы развития: [монография].Самара: Изд-во Сам. гос. экон. акад., 2005. 